\title{
Perfection Measures of the Teaching Mode for Colleges Visual Communication Design Major
}

\author{
Zhen Yang \\ Art college of xi'an university 710065
}

\begin{abstract}
Keywords: Colleges; Colleges visual communication design major; Teaching mode; Development history; Perfection; Measures
\end{abstract}

\begin{abstract}
With the continuous development of China's economy and the rising life standards of people, many emerging industries have been established. In order to better promote the development of these industries, the colleges in our country have designed many corresponding majors to them. Aimed at providing a steady flow of professionals for the developing industries. In this form, visual communication design major set by collages.Along with the continuous development of China's cultural industry, the professionals put forward a greater demand. It also made the teaching work of this major to a higher request. Based on this, we need to do some research on improving and innovate the teaching mode of visual communication design curriculum in colleges and the teaching quality of this major. Hope the study can be helpful for the development of practical work.
\end{abstract}

\section{Introduction}

In recent years, cultural soft power has become an important part of a country's comprehensive national strength. It deeply affecting the overall competitiveness of a country. Based on this, our country has increased the development intensity of cultural industries and the cultivation intensity of cultural professionals. In this situation, It is necessary for the relevant subject of colleges to discuss about innovating and perfecting the teaching mode of visual communication design major as well as improving the teaching quality. To develop more useful talents to work for the development of cultural industries in China and help to upgrade our cultural soft power and comprehensive competitiveness.

\section{The Historical Review of Colleges Visual Communication Design Major Teaching Job in Our Country}

The opening of colleges visual communication design major in our country was firstly began in 80 's last century. Now, it has possessed a certain scale and provided a large number of professionals for relevant industries. At that time, the reform and opening is just carrying out, setting up this major was aimed at complying with the internet age and meeting the needs of economic development in our country better. At the same time, the continuous adjustment of industrial structure and improvment of cultural industries status also put forward a greater demand and higher requirements to these professionals. What's more, with the continuous international communication on economic, political and cultural, foreign professionals and knowledge of this major gradually integrated into our country. Providing a certain experience and help for the development and expansion of this major ${ }^{[1]}$. Nowadays, the cultural industry is still in development, its role has become increasingly prominent. The government also put forward the concept „,cultural power“.It raised the requirements of relevant professionals to a higher lever.

\section{The Status Quo of Colleges Visual Communication Design Major Teaching Job in Our Country}

Colleges Teaching Mode and Teaching Thought Separating from Social Reality

Relevant survey shows that the related colleges basically have opened visual communication design 
major as long as they have design major. And this major also has been a veteran major through the long-term development of these colleges. But, with society changing and developing especially the modern scientific technology's improvement, traditional teaching ideas, modes and content no longer have ability to meet the actual needs of students' growth. Talents cultivated in this situation often can't well adapt to the specific requirements of the relevant work. Teacher groups in colleges are lack of the sense on keeping pace with the times, changing work concepts, improving teaching methods and content. They are still using the traditional teaching mode. They focus on professional knowledge teaching and lack of awareness about cultivating the relevant professional ability. What's more, the teaching content is too single to meet the needs of community for comprehensive talents. In this way, they may get good professional achievements, but it would be difficult for them to meet specific work requirements once they come into society. It is not conducive to the favorable operation of China's related industries and the sustainable development ${ }^{[2]}$.

\section{Pure College Modern Design Education Foundation Is Weak}

Now, although many colleges have opened design major and make college visual communication design major as a key program, they still have not provided necessary policy and financial support to this major. Especially with the rapid development of China's information technology, various professionals have begun to introduce a large number of related infrastructure or worked on course innovation. However, the current development situation of college visual communication design major in colleges is that many of them are still using traditional teaching concept. They want to cultivate students' professional ability and quality through decorating design courses and training their visual skills ${ }^{[3]}$. The traditional curriculum system still retains its original position and the relevant subject did not innovate and improve the related teaching system timely. In addition, the development of this course, if only rely on theoretical knowledge of the inculcation, is not for the development of related industries, training it is not able to provide a large number of high-quality talents for the related industries merely rely on teaching theoretical knowledge.Therefore, it is necessary to for the colleges to improve the teaching methods. But the reality is that many colleges didn't take rational advantage of the internet platform and related technology. Therefore, the teaching content can not be successfully launched and the established teaching objectives can't be achieved,either. The comprehensive quality of students also can't be promote effectively. In short, most colleges didn't take initiative to adapt to the changing times and developing trend when setting up the professional teaching work. They didn't lay a good foundation for the development of this major. $^{[4]}$

\section{Related Major in College Being Simple and Limited, High-Quality Comprehensive Talents in Great Demand}

Nowadays, in the process of carrying out the teaching work of visual communication design major in colleges, the course offered by colleges is very simple which can't meet the large demand of society for high quality and comprehensive talents. It's not hard to find that the courses most colleges carryed out are similar to the traditional courses when they carrying out the teaching work. Meanwhile, these courses tend to instruct theoretical knowledge rather than training their relevant professional ability. Teaching reform is continuously advancing. Theoretically, it should be started from the curriculum structure, teaching arrangements and add some expansions on this major. To make it meet the society's requirements for comprehensive talents better. But the reality is that many colleges did not carry out a deeper reasearch on original subject content in the process of advancing the teaching reform. As a result, there would not have the expansions on course and period $^{[5]}$. The traditional curriculum system still retains its original position and the relevant subject haven't timely made innovation and improvement to the teaching system. In this way, students in colleges can't receive comprehensive training and they can't meet the social Comprehensive requirements of talents. So every year on the "graduation season", there will be in such a situation: the community needs a lot of high-quality, comprehensive talents, but the graduates can't well meet their requirements; At the same time, a large number of graduates are facing with the dilemma of finding a job. It can be said that the irrationality of professional courses in colleges can not only affect the growth and development of students but also is not conducive to the expansion of relevant 
industries in China and the adjustment of structure ${ }^{[6]}$.

\section{Developing the Teaching Content and Method of Colleges Visual Communication Design Major in Practice}

\section{"Case Teaching Method" for the Training Development of Professional Courses in Colleges}

For the issues of low teaching efficiency, pertinence, speciality, comprehensiveness coming out with the work that colleges carryed out on visual communication design major, the relevant subject should actively explore the corresponding solutions. The application of "case teching method" undoubtedly indicated the direction for the teaching work of this course. The so-called "case teaching method" refers to a case-based teaching method that aims at giving full play to students' subjective initiative and strengthening the interaction between teachers and students ${ }^{[7]}$. It is generally started by providing the students some cases associated with teaching content, and then organically put students with different learning base, learning ability into group. Group work to analyze and discuss this case and fiding the existing problems. On the basis of comprehensive analysis of the problem to find corresponding solutions. And finally achieve profound understanding of the teaching content as well as deeper understanding.

\section{The Key Points Between Joint Development of Campus and Enterprise and Classroom Teaching Mechanism}

The joint development of campus and enterprise refers to the full use of the resources of both colleges and enterprise and adopt the talents training mode of combining classroom teaching and social practice to improve the efficiency and quality of talents training ${ }^{[9]}$. In this way, the college teaching work can obtain better results and enterprise can also the correspondingly reserve professionals for their operations and development which is undoubtedly a win-win situation. The time is limited for classroom teaching and teaching content is also limited by space. But if the school and the enterprise joint to carry out the teaching of students and training work, then you can well cover the shortage of single classroom ${ }^{[10]}$. Based on this, the college should widely understand the situation of different enterprises and set up a mechanism with them for students. Specifically, the teacher should focus on effective docking with the enterprise to ensure that with the classroom learning students can better complete business practice and requirement when doing classroom teaching work especially in setting teaching content. In addition, for the learning condition evaluation of students, the teacher can combine the school test results with business practice results. And improve the proportion of business practice results in evaluation results as much as possible. So as to make them pay attention to practice and improve their professional ability to lay a solid foundation for their becoming comprehensive social talents.

From the perspective of college students employment, based on social development needs

On the current employment situation of professional graduates, it mainly facing the following two problems: First, the ability and quality of graduates can't meet the requirements of enterprises.Therefore, most graduates often face with " employment difficulty ", " work difficulty "; On the other hand, for the the ability and quality of graduates can't meet the requirements of business operations and development they can only find experienced and competent professionals. Therefore, different enterprises would start competitions on talents and " labor difficulty " problem comes out. We found that the reason for the emergence of these problems is the issues with educational teaching methods in colleges as well as talents training mode ${ }^{[11]}$. On the one hand, the curriculum should focus on practicality and ensure its learning. It will play a positive role on improving students' professional skills and literacya to achieve the effective docking on classroom teaching content with students development practical needs; On the other hand, the college should improve the traditional curriculum system timely and do more reasearch on professional curriculum and constantly expand the course content, so as to better meet the demand of community for a large number of comprehensive talents. In addition, we should perfect training mechanism of combining production, learning and research and making the school talents training work carry out with more pertinence. To avhieve organic unity of the student growth and related industries development. 


\section{Promote the Reform of Curriculum System in Colleges, Improve the Construction of Experimental Teaching}

Nowadays, in the process of visual communication design professional teaching work, there have two main problems: One is not grasp the trend of changing times,lack of rational use of internet platform and related science and technology, and lacking of infrastructure construction investment[12]; On the other hand, the course arrangement in colleges is too simple which is not conducive to the cultivation of comprehensive talents. In view of these two problems, the relevant subjects in colleges should increase the capital investment for this professional teaching and give some policy support, so that the teaching equipment can be improved. It will be good for the students and help teachers to provide better teaching environment. Especially the investment on multimedia equipments which is very important for professional teaching. In addition, colleges should also do in-depth study of this profession and constantly improve the relevant curriculum system.To fully explore the relationship between this major and related industries development. And thus be more targeted to carry out courses, arrange classes and to achieve the value of teaching work better.

\section{Conclusion}

All in all, there still have many problems and loopholes in the process of carrying out the teaching work of colleges visual communication design major. It is not only bad for the carrying out of high quality and efficiency teaching, but also conducive to the growth and development of students. Thus there would have no hope for constantly providing professionals for China's related industries. Based on this, the relevant subject must increase the teaching work and curriculum structure design research efforts, so as to provide a theoretical basis when carrying out the actual work. Specifically, the relevant subject should start with the employment of college students, based on social development needs, and organicly combine the three elements of production, learning, research; At the same time,promote the reform of the curriculum system and improve the construction of experimental teaching.To provide policy protection, and material support for the development of relevant work. In addition, the teaching subject should also continue to innovate and improve their teaching methods, introduce "case teaching method" and other scientific teaching methods to achieve the effective upgrading of classroom teaching efficiency. I believe in the coordination of the main body and under the joint efforts of colleges, the colleges will be able to training a large number of high-quality talents for China's related industries.

\section{References}

[1] Z.Z. Li: A Probe into the Practical Approaches to the Development of "Integration of Production and Teaching" Development of Comminication Design Professional, (2017) No.09,p.305.

[2] H.J. Yu: Research on the Professional Structure of Visual Communication Design in Colleges and Universities Based on the Present Teaching Situation of Social Training Institutions, (2016) No.16,p.189.

[3] Y.Wang: Journal of Hubei Normal University (Journal of Philosophy and Social Sciences), (2016) No.4,p.103.

[4] ]J.F. Zhang: A Study on the Curriculum Management of Visual Communication Design Specialty in Chinese Non - governmental Institutions of Higher Learning (Northeast Normal University, 2016).

[5] F.B.Zou,X.N.Sun: Beauty and the Times (volume 1), (2015) No.12,p.123.

[6] X.Y.Shen: A Probe into the Application of "Visual Communication Design Specialty" in Reality, 2015.

[7] X.Bai: Drama home, (2014),No.16, p.146.

[8] Y.C.Li: Art Education Research, (2014), No.15, p.97.

[9] Q.Q.Yang: Art Education Research, (2014), No.12, p.80. 
[10] H.T.Liu: Research on the Development Trend of Visual Communication Design Education in Colleges and Universities in the Context of New Media (Zhejiang University of Technology, 2014).

[11]L.Y.Wang: Research on Practical Teaching of Visual Communication Design Specialty in Hebei Academy of Fine Art, (Hebei University, 2014).

[12] Y.Wang: College Education,(2014),No.3, p.119. 